\title{
Monetary Policy and Economic Growth in Developing Countries: Evaluating the Policy Nexus in Nigeria
}

\author{
Miftahu Idris \\ Department of Economics, Taraba State University, Jalingo, Nigeria \\ Email address: \\ miftahu4real12@gmail.com \\ To cite this article: \\ Miftahu Idris. Monetary Policy and Economic Growth in Developing Countries: Evaluating the Policy Nexus in Nigeria. International \\ Journal of Business and Economics Research. Vol. 8, No. 5, 2019, pp. 303-313. doi: 10.11648/j.ijber.20190805.17
}

Received: July 3, 2019; Accepted: August 7, 2019; Published: August 26, 2019

\begin{abstract}
While there are numerous studies on the relationship between monetary policy and economic growth, evaluating the policy nexus between the two phenomena remain inconclusive. Undeniably, monetary policy is believe to influence the employment level, price stability, growth of aggregate output and equilibrium in the balance of payment- for the case of developing economies. But the magnitude of its influence largely depends on how it is conducted through various channels and the independency of the apex bank to select the appropriate instruments for formulating the monetary policy. In lieu of that, this study examines the relationship between monetary policy and economic growth in Nigeria using time series data covering the period of 1980 to 2017. The study employs the Cointegration test and the Ordinary Least Square (OLS) technique with the view to estimating the model coefficients and showcase the policy nexus between the variables. Result indicates the existence of long-run relationship between monetary policy indicators and economic growth. Further empirical findings show that money supply has positive effect, while both exchange rate and interest rate have negative effect on the real GDP. As such, monetary authorities in Nigeria should adequately managed and monitored the growth level of money supply in order to realise the desired growth level. Given the socio-economic and political conditions in Nigeria, there is growing needs to formulate appropriate monetary measures which might encourage borrowing through sound and productive interest rate as well as stable exchange rate.
\end{abstract}

Keywords: Monetary Policy, Economic Growth, Cointegration Test, OLS Technique, Nigeria

\section{Introduction}

The capability of monetary policy to encourage aggregate output and prices particularly in the short-run is largely accepted in economic theory and well-documented by enormous time series analyses of monetary policy transmission. Monetary policy is highly essential because it plays a stabilising role in the economic system by addressing imbalances that affect aggregate productivity and growth level through a number of channels. Though, the scope of monetary role might be limited by the nature of monetary policy transmission mechanism, the uncertainty surrounding the policy makers and the stance of economic policies. In every economy, the central or apex bank uses the instruments of monetary policy to influence the liquidity level and the composition of interest rate within the banking institutions in accordance with the prerequisite of monetary and banking stability towards enhancing economic growth. Since a sustained rise in price is significantly a monetary phenomenon, the monetary policy utilises its instruments to efficiently moderate the level of money supply towards ensuring price stability both in the medium and long terms. Furthermore, it also influences expectations about the future direction of economic activity and inflation, thereby affecting the prices of goods, asset prices, exchange rates, consumption and investment levels. Accordingly, monetary decision of lower interest rate may result in high investment activities and the purchase of durable consumer goods. The expectations that the tempo of economic activities might increase will equally trigger the commercial banks and other lending institutions to ease borrowing policies, hence allowing the household and business entities to increase spending.

The Nigerian economy is still recovering from the economic recession that hit the nation two years ago and the high level of accumulated debts that lingers due to heavy 
borrowing. Growth rate was weak and dismal, high prices of goods and services, increased unemployment level and the fluctuating exchange rate. From 2016 to 2017, the economy exist amidst the global environment with low growth rate compared to other oil-producing nations, weak and unstable productivity level, high inflation with stagnant wage growth, low business investment, dominance of the oil sector, rising poverty level, and decreased terms of trade. With the introduction and full implementation of the Economic Recovery and Growth Plan (ERGP) by the Buhari-led administration, numerous achievement was recorded. However, attaining macroeconomic stability does not only depends on the nation's management, but also on the structure and composition of key market actors. To encourage macroeconomic stability, there is ample need to support aggregate policies and structural reform programmes which may strengthen and improves the market condition as well as the other essential sectors. These policies are expected to create an enabling environment for long-term investment, rapid and sustainable growth as well as accommodate and adapts to the growing challenges over time.

From the review of the literature, it is crystal clear that there exist numerous channels through which monetary measures are transmitted into the real economy thereby affecting aggregate output. These channels includes money supply, exchange rate, interest rate, inflation, cash reserve ratio, etc. As for the money supply and interest rate, most literature indicate a significant and positive impact, while inflation established a negative effect. While the literature shows that different monetary policy tools have different impacts on economic growth and inflation, most of these conclusions are contrary to the expectations as emanate from the theory. Yet, there is no agreement among scholars as to why certain monetary policy indicators do not affect the aggregate output level. A large number of studies have examined the effects and the causality relations of monetary policy in Nigeria using various techniques and frequencies with limited time range. But none have evaluated the relationship comprehensively taking into cognisance the various dimensions of the literature. However, this study postulates that for the government to achieve its desired level of sustained growth, effective and efficient monetary policy measures need to be established.

In lieu of that therefore, this study examines the effects of monetary policy indicators on real GDP (economic growth) using recent data with high frequency to cover the limitations of the previous studies. To achieve that, this study raises some questions with the view to guiding the research: Do monetary policy indicators (money supply, exchange rate, interest rate) have positive impacts on the Nigerian economic growth? This, among other observations, are critically evaluated while valid inferences are drawn. The remaining part of this study is divided into sections: section 2 deals with literature review highlighting various contributions from the literature on the significance of monetary policy towards national development; section 3 contains the materials utilised for the study including the data source and its relevance as well as the methodology employed to analysed the impact relationship; section 4 presents the empirical findings from the estimate coefficients and its position amidst the current trend of literature; section 5 deals with the concluding remarks in addition to the highlighted policy suggestions that are both feasible and viable to the government.

\section{Review of the Literature}

Various authors have examined the impact of monetary policy on the sustainable economic growth and development in various countries including developed and developing economies. Although the literature is divided over its impact; while others support a positive impact of monetary policy on economic growth, certain studies show evidence in favour of negative impact. A good number of these studies are reviewed and synthesis in the following sub-sections.

\subsection{Positive Impact of Monetary Policy}

Literature that argued on the positive effects of monetary policy while showing support in favour of classical school of thought includes the followings: Nwoko and Ihemeje (2016) examine the impact of monetary policy as conducted by the Central Bank of Nigeria towards accelerating rapid and sustainable economic growth using the annual data covering the period of 1990 to 2011 [1]. The conventional multiple regression technique is adopted as an instrument of analysing the coefficient. Results indicate that monetary policy measures are effective in regulating both the monetary and real sector aggregates such as employment, prices, level of output and the rate of economic growth. In the same vein, Anowor and Okorie (2016) examine the impact of monetary policy on the economic growth of Nigeria by applying the error correction mechanism and the Johansen cointegration test on the annual data covering the sample period of 1982 to 2013 [2]. Among other policy measures, result indicates that monetary policy is determine and effective in enhancing the macroeconomic objectives of sustainable growth and price stability.

As maintained by Duskobilov (2017), monetary policy is an integral part of economic development strategy in any economy due to its significant impact on economic sustainability [3]. The author investigates the impact of monetary policy tools on economic regulation in Uzbekistan by analysing the relationship between monetary policy tools and economic growth. Using cointegration and error correction model, results show that monetary policy tools influenced economic growth positively with a long-term relationship. Furthermore, Ahmad, Afzal and Ghani (2016) evaluate the significance of monetary policy in enhancing the economic growth of Pakistan using time series data spanning 1973 to 2014 [4]. By employing the Autoregressive Distribution Lag (ARDL) model to determine the robustness among the variables with specification of short-run and longrun relationship, findings show that monetary policy 
variables have a significant and positive impact on economic growth. In addition, Onyeiwu (2012) examines the impact of monetary policy on the economic growth of Nigeria using annual data covering the period of 1981 to 2008 [5]. The author adopts the Ordinary Least Squares (OLS) technique to measure the impact of the relationship. The result of the analysis shows that monetary policy (proxy by money supply) exerts a positive impact on GDP growth and balance of payment but negative impact on inflation rate.

In addition, Lennard (2018) examines the impact and causal relationship of monetary policy using the British economy during the period of classical gold standard [6]. Using the ordinary least square regression method in relation to the narrative approach, one percentage decrease in monetary policy measures, causes an eventually increase in the unemployment by $0.9 \%$ while inflation decrease by $3.1 \%$. Moreover, the monetary policy shocks accounted for the larger proportion of variation in macroeconomic volatility. In the same vein, Chang, Chen and Chang (2013) investigate the effects of economic growth and social welfare implications of monetary policy in an endogenous growth model with endogenous fertility [7]. Together with a balanced growth path, monetary growth increases fertility and reduces the economic growth rate if consumption and real balances are complements or are independent. However, monetary expansion may decrease fertility and increase economic growth if consumption and real balances are substitutes. Moreover, Afrin (2017) examines the transmission mechanism of monetary policy in Bangladesh by exploring the lending rate and the exchange rate channels during the period of market based monetary instrument and the float exchange regime [8]. Results indicate that monetary aggregates targeting framework is still effective in influencing price level. Also, bank lending plays a non-trivial role, while the exchange rate channel is less effective in the transmission process, suggesting a high degree of intervention in the foreign exchange market.

Furthermore, D'Aguanno (2018) investigates the international transfer based on how the dividend income affects monetary policy in a two-country model with ineffective financial system [9], and further measures the macroeconomic shocks and how its affect international transfer payments and determine cross-border wealth effects on labour supply, output and consumption. The direction of these effects depends on the nature of the underlying disturbance: technology and wage mark-up shocks cause wealth effects that stabilise consumption relative to output, whereas monetary and price mark-up shocks cause wealth effects that destabilise it. Enormous literature shows this relationship affects the balance of monetary policy between inflation and output stabilisation. Likewise, Bhattacharya, Haslag and Martin (2009) study an overlapping generation economy with capital where limited communication and stochastic relocation create an endogenous transactions role for fiat money [10], and further examine the potential limitation of Friedman's logic using the Tobin's argument. The Friedman rule is not welfare maximizing even in the presence of endogenous long-run growth. Additionally, it is inconsistent with maximum growth. Knowingly, models of endogenous growth a la Romer produce equilibria within efficiently low levels of investment because the social return to capital investment is higher (due to the knowledge externality) than the private return. Further evidence by Smith (1998) established that, the Friedman rule cannot cure this inefficiency [11]. Raising the money growth rate via the Tobin effect fosters private capital investment and hence improves welfare.

In a related development, Twinoburyo and Odhiambo (2018) employ a descriptive approach to survey the existing theoretical and empirical literature on the impacts and possible relationship between monetary policy and economic growth [12]. The authors further take a comprehensive view of the theoretical evolution of the relationship and the respective recent empirical findings on the examined variables. Even though the study is purely contextual, it concludes that monetary policy is effective towards economic growth particularly in developed and financially buoyant economies. But, the relationship appears weak and unstable in developing countries with structural and institutional defaults. More so, Reed and Ghossoub (2012) investigate the effects of monetary policy using neoclassical growth model where money is required for investment and consumption purposes [13]. In contrast to standard cash-in-advance models, the reliance on cash is inversely related to the extent of capital formation, and further shows that the impacts of monetary policy depends on the level of country's development. The study established that, inflation adversely affects capital formation at low income levels because there is a high reliance on cash and a high cost of capital. By comparison, the financial system operates more efficiently in advanced countries than developing economies.

While measuring the impact of monetary shocks, Aastveit, Natvik and Sola (2017) use several measures of U.S. economic uncertainty and estimate its interaction with monetary policy shocks as identified through structural vector autoregression modes [14], and further examine whether economic uncertainties changes the macroeconomic influence of monetary policy. Result shows that the U.S monetary policy shocks affect economic activity less when uncertainty is high but the impact on investment level remains moderate. According to Kaminska and Roberts-Sklar (2018), there should be a strong link between monetary policy rate uncertainty and equity return volatility both in theory and data [15]. The authors adopt the regression-based projections for realised variance to examine the relationship between short horizon forecasts of equity variance and proxies for monetary policy rate uncertainty. By assessing various projection models for UK, US and Euro area equity indices, the study further indicate that the proxies for monetary policy rate uncertainty have a significant and positive predictive power for the equity return variance. Adding monetary policy rate uncertainty variables can significantly improve forecasting models for equity variance and volatility at weekly, monthly and even quarterly horizon. 
Besides, Cantelmo and Melina (2018) utilise the Structural Vector Autoregression (SVAR) model to examine the impact of relative price of durable goods to a monetary policy contraction in the US economy [16]. Result shows either a flat or mildly positive outcome but the findings are rationalised through the estimation of a two-sector new Keynesian models. Durables prices are estimated to be as sticky as those of nondurables, leading to a flat relative price response to a monetary policy shock. More to that, Colletaz, Levieuge and Popescu (2018) examine the existence of a systemic risk-taking channel in the Eurozone through an original macroeconomic perspective based on short-term and long-term causality measures [17]. Results indicate that causality from monetary policy to systemic risk remain insignificant in the short-term, robustly represents $75 \%$ to $100 \%$ of the total dependence between the two variables in the long-run. Reverse causality is rejected: systemic risk did not influence the policy of the European Central Bank before the global financial crisis.

More so, Najal (2017) explores the impact of monetary policy on the economic development of Pakistan over a sample period of 1982 to 2009 [18]. The author utilised the OLS technique with the view to estimating the model coefficients. Results indicate that monetary policy has a positive and significant impact on the economic growth of Pakistan within the period under consideration. Similarly, Adigwe, Echekoba and Justus (2015) examine the impact of monetary policy on the economic growth of Nigeria using annual time series data covering the period of 1980 to 2010 [19]. The authors employ the OLS estimation technique to analyse the data collected and draw conclusions. Findings indicate the existence of positive and significant impact of monetary policy (proxy by money supply) on the economic growth of Nigeria for the period under review.

Nevertheless, Zhao, Chen and Hao (2018) examine how the relationships between the local governments and local enterprises moderate the effect of targeted monetary policies through different action-propagating mechanisms [20]. The authors adopt a different approach by measuring the impact of monetary policies on enterprise investment in areas with different institutional environments; investigate the impact of monetary policies on state-owned enterprises with different property rights structures; and finally assess how political connections can influence the action-propagating mechanism of monetary policies. Result shows that monetary policies have different effects on state-owned enterprises and on private enterprises with or without political connection in China. Likewise, Visokavičienè (2014) investigates the impact of monetary policy in Lithuania during the global financial crisis using the techniques of logical analysis and systemising of academic literature and modelling of the monetary policy [21]. It should be noted until the introduction of euro, Lithuania does not have a monetary policy; as such, it applies the currency board regime pegging the litas invariably to the euro (hard peg regime). Given this unstable condition, it seems not only problematic but also risky in achieving financial and economic stability. Results indicate that the introduction of euro for Lithuania resulted to relative stability through the monetary policy of the European Central Bank.

As argued by Sulaiman and Migiro (2014), monetary policy is directed towards creating stability and encouraging growth in the economy [22]. The authors examine the relationship between monetary policy and the economic growth in Nigeria using time series data covering the sample period of 1981 to 2012 . Using the cointegration test and the Granger causality technique, findings indicate the existence of positive and long-run relationship between monetary policy indicators and economic growth while the Granger causality impact shows a unidirectional causality running from monetary policy to the economic growth. In presenting the findings of a meta-analysis by identifying the causes of variation in the impact of monetary policies on economic development, Ridhwan, de Groot, Nijkamp and Rietveld (2010) employ sample observations that are drawn from primary studies which homogeneously adopt the VAR technique [23]. Findings reveal that the inflation rate, financial deepening, economic size, and capital intensity are the significant measures in explaining the variation in outcomes across regions and over time.

However, Ayodeji and Oluwole (2018) examine the impact of monetary policy on the economic growth of Nigeria by developing a framework with full potential to explore how government monetary policy affected economic growth through the use of time series data covering 1981 to 2016 [24]. By adopting the cointegration test, error correction model and the Granger causality technique, results indicate the presence of positive, long-run and short-run relationship between monetary policy and economic growth; while the causality test reveal the existence of unidirectional causality between money supply and economic growth. In a related development, Dimitrijević and Lovre (2013) review some essential measures of monetary policy by evaluating the circumstances when it is possible for the money supply to become the source of economic growth without imposing inflationary implications [25]. The authors further investigate the demand and supply functions for money, the quantity theory of money, velocity of circulation and instruments of monetary policy and strives to propose such a combination of measures of a new economic policy based on theoretical arguments that will stimulate economic growth. Given the significant relationship between money supply and real GDP, it implies the presence of positive impact of monetary policy on economic growth.

Similarly, Obeid and Awad (2017) examine the impact of monetary policy instruments on the aggregate performance of the Jordanian economy using quarterly data covering the sample period of 2005 to 2015 [26]. To estimate the statistical model, Johansen cointegration test and the vector error correction model are adopted to measure the significance of the monetary indicators on economic growth. Findings show the existence of a positive impact between the examined variables both in the short-run and the long-run. To provide further evidence, Chaudhry, Qamber and Farooq 
(2012) investigate the long-run and short-run relationships between monetary policy, inflation and economic growth in Pakistan using co-integration and causality analysis covering the sample period of 1972 to 2010 [27]. Findings show that credit to private sector, the variable of financial depth, real exchange rate and budget deficit are significant and further influences the real GDP in Pakistan. The pair-wise Granger Causality results suggest that the relationship between real GDP and real exchange rate is bi-directional, while real GDP to financial depth, domestic credit and budget deficit is unidirectional.

Likewise, Agbonlahor (2014) investigates the impact of monetary policy on the economic growth of United Kingdom (UK) using the annual time series data covering a sample period of 1940 to 2012 [28]. To estimate the model coefficients, Vector Error Correction Model (VECM) is utilised and the results indicate the existence of long-run relationship among the monetary policy indicators. In other words, inflation rate and the money supply are positive and significant elements of monetary policy that encourage the aggregate output growth in the UK economy. Similar to that, Fasanya, Onakoya and Agboluaje (2014) investigate the impact of monetary policy on the economic growth of Nigeria using annual data spanning the sample period of 1975 to 2010 [29]. In addition to the Keynesian IS-LM function and the cointegration test, the effects of stochastic shocks of each of the endogenous variables are examined using the error correction model. Results indicate the presence of long-run and short-run relationship among the variables; while monetary policy has a strong and positive impact on the economic growth.

By adopting the regression coefficients and the error correction mechanism, Alavinasab (2016) examines the impact of monetary policy on the economic growth of Iran over the sample period covering the 1971 to 2012 [30]. The estimated results indicate the existence of long-run relationship between money supply, exchange rate, inflation and real GDP. Meaning that, monetary instruments have a positive and significant impact on the economic growth of Iran for the period under consideration. On the other hand, Komijani, Sargolzaei, Ahmad and Ahmadi (2012) investigate the unexpected asymmetric effects of money on production and inflation [31]. Respective concerns of monetary policy making deals with how unanticipated variations adjust production and level prices. Results indicate that sudden monetary decrease has high impact on the economic growth in contrast to unexpected monetary increase; while unexpected monetary increase has greater effect on inflation relative to the unexpected monetary decrease. However, Kamaan (2014) explores the effect of monetary policy on the economic growth of Kenya using quarterly data spanning 1970:Q1 to 2012:Q4 [32]. The author employs the VAR estimation technique to draw inferences and further conclusion. Results show that, an unexpected and temporary increase in the interbank rate of the Kenya's central bank does not correspond to the increase in output growth. In addition, interest rate channel is the most operational channel of monetary policy transmission on inflation in Kenya within the period under consideration.

\subsection{Negative Impact of Monetary Policy}

Empirical literature that argued on the negative impact of monetary policy while showing support in favour of Keynesian school of thought includes the followings: Inam and Ime (2017) investigate the impact of monetary policy on the economic growth of Nigeria using annual data covering the period of 1970 to 2012 [33], and further determine the nature and direction of causality between money supply and real GDP. The authors applied the OLS technique and the granger causality test for the analysis, hence findings show a positive but insignificant relationship between money supply and economic growth while the causality indicates no causal effect between the money supply and economic growth. In addition, Lut and Moolio (2015) examine the impact of monetary policy on the economic growth of Cambodia by utilising quarterly time series data spanning the period of 2000 to 2012 [34]. The authors employ the multiple regression model to measure the impact of money supply and interest rate on GDP growth in Cambodia. Findings indicate that money supply has a positive but weak impact while change in interest rate remains insignificant on economic growth. As such, monetary policy appears weak and unstable in enhancing economic growth of Cambodia.

Furthermore, Younsi and Nafla (2017) examine the relationship between financial stability, monetary policy, and economic growth in 40 developed and developing countries by using the annual panel data covering the sample period of 1993 to 2015 [35]. To do this, fixed and random effects panel data regression models were fitted to determine the impact of financial stability and monetary policy on economic growth. Results indicate that monetary policy indicators exert a negative impact on economic growth and by extension to the financial stability and development, respectively. Likewise, Precious and Palesa (2014) examine the essential role played by the monetary policy in promoting economic growth in the South African economy over the sample period of 2000 to 2010 [36]. Using the Johansen cointegration and the error correction mechanism to evaluate the long-run and short-run relationship, findings indicate the existence of a long-run relationship among the concerned variables. While the remaining monetary policy instruments appears insignificant, only inflation rate is significant for the period under consideration.

In the views of Obadeyi, Okhiria and Afolabi (2016), monetary policy plays a crucial role in financial growth and development both in developed and developing countries [37], but the policy measure is constrained by fiscal dominance, high cost of funds and high inflation. Although exchange rate, interest rate, money supply and foreign reserve are among the important indicators of monetary policy which can determine the economic growth. The authors investigate the impact of monetary policy on the growth of Nigeria economy using data from 1990 to 2012. By using the Ordinary Least Square (OLS) technique assess 
the relationship among the variable, results show the inability of the Central Bank to control the money supply and bank credits which are regarded among the significant tools for measuring and proffering solution to the substantial credit spreads between short-term central bank policy rates and the rates facing households and firms in the economy. More so, Srithilat and Sun (2017) examine the impact of monetary policy on the economic development of Lao PDR using the annual time series data covering the period of 1989 to 2016 [38]. Using the Johansen cointegration and the error correction model to analyse the possible relationship among the variables, results established that money supply, interest rate and inflation rate has a negative effect on the real GDP per capita in the long run; only real exchange rate has a positive sign.

In the words of Adediran, Mathew, Olopade and Adegboye (2017), the essential of monetary policy to economic growth has made its significance to be strong in achieving economic growth among various economies [39]. The authors investigate the relationship between monetary policy shocks and inclusive growth in Nigeria. With many of the macroeconomic models for measuring the effect of monetary policy on an economy lacking the analytical specificity to account for the importance of shocks on aggregate economy, the study employ the annual data from 1980 to 2014 on the VAR methodology. Result shows the inability of the monetary policy authority to control the instability of the exchange. This however, is largely responsible for noninclusiveness of growth experienced in Nigeria. Likewise, Njoku and Susan (2016) examine the impact of monetary policy on economic stability in Nigeria and the level of success recorded in contrast to its stated regulatory goals using annual data spanning 1986 to 2013 [40]. To estimate the data and further avoid non-stationarity challenges, Johansen cointegration and the multiple regression model are utilised. Cointegration result affirm the presence of long-run relationship between the variables, while the multiple regression estimates shows that monetary policy instrument (exchange rate) has a significant impact on inflation rate while other explanatory variables (cash reserve ratio, liquidity ratio and interest rate) shows a negative impact.

Using the ARDL model, Twinoburyo and Odhiambo (2016) investigate the short-run and long-run impact of monetary policy on the economic growth of Kenya covering the sample period of 1973 to 2013 [41]. The authors adopt the broad money supply and the treasury-bill rate as proxies of monetary policy. Results indicate no effects of monetary policy on economic growth (monetary policy neutrality) both in the short-run and the long-run. This could be due to the fact that the increasing fiscal deficits funded domestically in Kenya could have weakened the transmission of monetary policy actions into the real economy. Similarly, Njimanted, Akume and Mukete (2016) explore the effects of certain key monetary policy variables on the economic growth of CEMAC zone within the sample period covering 1981 to 2015 [42]. By utilising the Ex post facto research design based on the principal components selection approach, the authors used interest rate, inflation rate, economic growth and money supply on the VAR method. Result indicates that key monetary policy variables influence economic growth of the CEMAC zone in various conducts. Moreover, the interest rate and inflation accumulated a significant and destabilising impacts on the economic growth.

Moreover, Ezeaku, Ibe, Ugwuanyi, Modebe and Agbaeze (2018) investigate the industry effects of monetary policy transmission channels in Nigeria within the sample period of 1981 to 2014 on time series data [43]. Using the Johansen cointegration test and the error correction model, result shows that monetary policy transmission channels jointly have a long-run relationship with real output growth of the industrial sector. More so, the regression estimates indicate that the private sector credit, interest rate, and exchange rate channels have negative effects on real output growth both in the long-run and short-run. Relatively, the extent of the effects are higher in the long-run than the short-run period. In the same vein, Mallick (2011) examines the impact of monetary policy along with relevant macroeconomic factors on the growth of construction sector and housing prices in the Indian context [44]. Using the regression analysis, findings indicate that it is mainly commercial bank credit from supply side and rise in income in demand side have positive influences on the construction sector growth. While measuring the influence of other determinants of housing prices, it reveals that inflation rate exerts higher pressure and money supply shows a decreasing force.

\subsection{Monetary Policy, Inequality and Financial Development}

Another strand of the literature examined the impact of monetary policy on inequality (distributional effects) and financial development in various nations. Certain number of these studies includes the following contributions: Furceri, Loungani and Zdzienicka (2018) provide new evidence on the effect of conventional monetary policy shocks on income inequality [45], by constructing a measure of unanticipated changes in policy rates (changes in short-term interest rates that are orthogonal to unexpected changes in growth and inflation rates) for a panel of 32 advanced and emerging market countries over the sample period covering 1990 to 2013. Findings show that contractionary monetary policy shocks increase income inequality. In addition, while an unexpected increase in policy rates increases inequality, changes in policy rates driven by an increase in growth and inflation are associated with lower inequality. Similar to that, Mumtaz and Theophilopoulou (2017) employ the micro level information to construct quarterly historical measures of inequality from 1969 to 2012 using the UK economy [46], and further examine whether monetary policy shocks play a role in explaining the increase in inequality. Findings show that contractionary monetary policy shock causes an increase in earnings, income and consumption inequality and contribute to its fluctuation. The response of income and consumption at different quantiles suggests that contractionary policy has a larger negative effect on low 
income households and those that consume the least when compared to those at the top of the distribution.

In addition, Voinea, Lovin and Cojocaru (2018) use a particular model to examine the relationship between household debt and the transmission mechanism of monetary policy in an EU Member state with independent monetary policy and high income inequality [47]. From Romania, result shows that household's reaction to variations in monetary measures depends on their income and indebtedness profile. The transmission of monetary policy is more effective for middle income households, which are more indebted and have adjustable rates, as lower policy rates ease the consumption constraints on these households. Low income households respond mainly to budgetary policies, as the increase in disposable income matters most for the bottom quintile. Top income quintile reacts more to monetary policy than bottom quintile, but less than middle income quintile. However, Davtyan (2017) evaluates the distributional effect of monetary policy [48]. The empirical analysis is implemented for the US economy, where the dynamics in income inequality is mainly driven by the variation in the top one percent of the income distribution. The author utilised the inequality measures that represent the whole income distribution while the distributive effect of monetary policy is assessed using various frequency data. Estimated results using the cointegration and the vector error correction model reveal that contractionary monetary policy decreases income inequality.

According to Ippolito, Ozdagli and Perez-Orive (2018), monetary policy can directly affect the liquidity and balance sheet strength of firms through existing loans [49]. The authors established that financially constrained firms with more unhedged loans display a stronger sensitivity of its stock price, cash holdings, inventory, and fixed capital investment to monetary policy. This effect disappears when policy rates are at the zero lower bound, revealing a new limitation of unconventional monetary policy. Contrary to the argument, Balafas, Florackis and Kostakis (2018) provide comprehensive evidence on the return response of financially constrained firms listed on London Stock Exchange (LSE) to UK monetary policy shocks extracted from the Bank of England's MPC meetings relative to expectations embedded in interest rate future prices during the period of June 1999 to December 2011 [50]. By using a large number of financial constraints proxies, the authors find no significant evidence that the most constrained firms' returns are more responsive to monetary policy shocks relative to the least constrained ones, as the credit channel of the monetary policy transmission mechanism would suggest. The results further reveal that the inverse relationship between interest rate shocks and UK stock returns reversed its sign and became significantly positive during the recent financial crisis period.

In supporting the argument, Matousek and Solomon (2018) established that the policy of consolidation and restructuring by the Central Bank of Nigeria from 2002 to 2008 has strengthen the bank's lending rate channel [51]. By using the Generalised Method of Moments (GMM) two step estimator to test the existence of bank's lending rate among sample of 23 banks, findings indicate that the loan growth is more sensitive to changes in bank size and capitalization. Furthermore, the restructuring polices of the central bank has rapidly improved the impact of the lending rate. In a divergent views, Ma and Lin (2016) investigate the relationship between financial development and the effectiveness of monetary policy using a panel data from 41 economies [52]. The results show that the effects of monetary policy on output and inflation are significantly and negatively correlated with financial development, indicating that the effectiveness of monetary policy declines as the financial system becomes more developed.

\section{Materials and Methods}

This study employs the time series data obtained from the official publication of the Central Bank of Nigeria (CBN) covering the sample period of 1980 to 2017. The study intends to develop a model that is capable of examining how monetary policy indicators affect the Nigerian economic growth over a certain period of time. However, in order to examine the relationship between money supply, exchange rate, interest rate and economic growth, the study employs the Ordinary Least Square (OLS) technique and the Johansen Cointegration test to determine the nature of the linkage between the variables. The model is specified as follow:

$$
\mathrm{GDP}_{\mathrm{t}}=\mathrm{f}\left(\mathrm{MS}_{\mathrm{t}}, \mathrm{EXR}_{\mathrm{t}}, \mathrm{INR}_{\mathrm{t}}\right)
$$

Where,

$\mathrm{GDP}_{\mathrm{t}}=$ real GDP (proxy for economic growth)

$\mathrm{MS}_{\mathrm{t}}=$ Money supply

$\mathrm{EXR}_{\mathrm{t}},=$ Exchange rate

$\mathrm{INR}_{\mathrm{t}}=$ Interest rate

Thus, equation (1) is translated into algebraic expression while incorporating econometric features as follows:

$$
\mathrm{GDPt}=\beta_{0}+\beta_{\mathrm{t}}+\beta_{1} \mathrm{MS}_{\mathrm{t}}+\beta_{2} \mathrm{EXR}_{\mathrm{t}}+\beta_{3} \mathrm{INR}_{\mathrm{t}}+\varepsilon_{\mathrm{t}}
$$

Since all the variables are not of the same unit of measurement (some are presented in billions while others in decimal), logarithm transformation of the variables is taking to ensure appropriate scaling among the collected data. As such, equation (2) is transformed into natural $\log$ and presented as follows:

$$
\log \mathrm{GDP}_{\mathrm{t}}=\beta_{0}+\beta_{\mathrm{t}}+\beta_{1} \log \mathrm{MSt}+\beta_{2} \log \mathrm{EXR}_{\mathrm{t}}+\beta_{3} \log \mathrm{INR}_{\mathrm{t}}+\varepsilon_{\mathrm{t}}(3)
$$

Where, $\beta_{0}=$ intercept or constant term; $\beta_{\mathrm{t}}=$ linear time trend; $\varepsilon_{\mathrm{t}}=$ error term

$\beta_{1}, \beta_{2}, \beta_{3}, \beta_{4}$ are the parameters to be estimated and are assume to be non-negative.

As presented in equation (3), the model is utilised to examine the effects and the relationship between monetary policy and economic growth in Nigeria the period under consideration.

\section{Results and Discussion}

In this section, the estimated findings are presented in line 
with the current trend of the literature. This is to showcase the significance of the study and its contributions to the practical world. A number of procedures are employed during the estimation process; and includes the unit root testing, presentation of regression results and the cointegrating relationship. These are presented in the following sub-sections accordingly.

\subsection{Unit Root}

To check the stationarity property or otherwise of the data obtained, Augmented Dickey-Fuller (ADF) and the PhillipsPerron (PP) tests are utilised. This is necessary in order to avoid the use of spurious regression which occurred when non-stationary series are estimated. Results for these tests are presented as follows:

Table 1. Results of the ADF unit root.

\begin{tabular}{|c|c|c|c|c|c|c|}
\hline Variables & t-statistics & ADF statistic 1\% & ADF statistic 5\% & ADF statistic $10 \%$ & P-value & Stationary \\
\hline GDP & -6.39 & -4.24 & -3.54 & -3.20 & 0.0000 & $\mathrm{I}(2)$ \\
\hline MS & -3.93 & -4.30 & -3.57 & -3.22 & 0.0231 & $\mathrm{I}(0)$ \\
\hline EXR & -4.14 & -4.23 & -3.54 & -3.20 & 0.0124 & $\mathrm{I}(1)$ \\
\hline INT & -5.49 & -4.24 & -3.54 & -3.20 & 0.0004 & $\mathrm{I}(1)$ \\
\hline
\end{tabular}

Table 2. Results of the PP unit root.

\begin{tabular}{|c|c|c|c|c|c|c|}
\hline Variables & Adj. t-stat & PP statistic 1\% & PP statistic 5\% & PP statistic $10 \%$ & P-value & Stationary \\
\hline GDP & -10.61 & -4.24 & -3.54 & -3.20 & 0.0000 & $\mathrm{I}(2)$ \\
\hline MS & -6.33 & -4.23 & -3.54 & -3.20 & 0.0000 & $\mathrm{I}(1)$ \\
\hline EXR & -4.72 & -4.23 & -3.54 & -3.20 & 0.0029 & $\mathrm{I}(1)$ \\
\hline INT & -6.84 & -4.23 & -3.54 & -3.20 & 0.0000 & $\mathrm{I}(1)$ \\
\hline
\end{tabular}

Information available in Table 1 and Table 2 present the results of unit root testing based on the $\mathrm{ADF}$ and $\mathrm{PP}$ approaches, respectively. The estimation is conducted without and with linear trend, but the results appear more significant when trend is included. As such, the variables are estimated using the linear trend as aforementioned in equation (3). However, the real GDP (GDP) does not exhibit stationary in both tests unless at the second difference in all levels of significance. While money supply (MS) is stationary at level in ADF, it shows stationarity at first difference in PP test at all levels of significance. For the exchange rate (EXR) and interest rate (INT), the parameters indicate first difference stationary both in ADF and PP test at $5 \%$ and $10 \%$ significance levels, respectively. Since all the variables are stationary, it provides the basis for further estimating the possible relationship that might exist among the coefficients.

\subsection{Regression Results}

The OLS technique is adopted to estimate the variables and further depicts the impacts relationship between the monetary policy indicators and the economic growth. The results are presented as follows:

Table 3. Result of the regression coefficient.

\begin{tabular}{lllll}
\hline Variable & Coefficient & Std. Error & t-statistic & P-value \\
\hline MS & 0.2169 & 0.0073 & 29.7069 & 0.0000 \\
EXR & -0.1032 & 0.0476 & -2.1699 & 0.0371 \\
INT & -0.3911 & 0.0952 & -4.1084 & 0.0002 \\
C & 10.4431 & 0.4729 & 22.0797 & 0.0000 \\
\hline
\end{tabular}

$\mathrm{R}^{2}=0.96$

Adj. $R^{2}=0.96$

Prob (F-statistic) $=0.0000$

Table 3 presents the result of regression estimates where real GDP is regressed on the money supply (MS), exchange rate (EXR) and the interest rate (INT). The coefficient of money supply (MS) shows a positive sign with significant $\mathrm{p}$ value at all levels; indicating that one percent increase in money supply might cause an eventual increase in the real GDP by $0.21(21 \%)$. This implies the existence of positive and direct relationship between money supply and the economic growth. Consequently, increase in money supply serves as an injection into the economy thereby boosting investment, export and aggregate production level. The economy by this trend might experience stability in the balance of payment equilibrium while the overall economy will be well-position in the international market; thereby leading to the attainment of desired level of economic growth. For the coefficient of exchange rate (EXR), it depicts a negative coefficient with significant p-value at 5\% level. Meaning that, one percent increase in the level of exchange rate might leads to a decrease in real GDP by $0.1(10 \%)$ hence, establishing a negative and inverse relationship between exchange rate and economic growth. This however, conform to the a priori expectation that high exchange rate (in relation to highly industrialised countries) might lower the value of the local currency, decrease economic and social welfare, affect local production and distribution, heighten the poverty level.

Moreover, the coefficient of interest rate (INT) reveals a negative sign with significant $\mathrm{p}$-value at $5 \%$ level. This implies that one percent increase in interest rate might leads to a decrease in real GDP by 0.39 (39\%) hence demonstrating an inverse relationship between interest rate and economic growth. By implications, high interest rate might diffuse into the economy in the form of decrease investment and employment thereby impacting on the income level and the aggregate output. The multiplier effects of these transmission might result in lowering the aggregate production level and thus affecting the overall economic development. In addition, the value of $\mathrm{R}^{2}$ is 0.96 indicating 
that $96 \%$ of the changes in real GDP is caused by the money supply, exchange rate and the interest rate levels, hence only $4 \%$ is accounted by other variables. Accordingly, the overall probability value of F-statistic for this estimate is significant at all levels, implying the joint significance of independent variables in explaining the variation in dependent variable. In other words, the F-statistics is used to depict if the explanatory variables in the model are jointly significant in explaining the variation in the dependent variable.

Given the results of monetary policy indicators, it can be deduced that all findings are consistent with the a priori expectations of this study and the economic theory: increase in money supply rises the GDP level; high exchange rate affect productivity level thereby decreasing output growth; while high interest rate discourage household and business entities for seeking fresh loanable funds from commercial banks and other borrowing institutions thereby affecting the tempo of economic activities, decrease investment level and by extension the aggregate output growth. With these findings, the study established that money supply is positive, while both exchange rate and interest rate have a negative effect on the real GDP for the period under review. The result is consistent with the literature by Srithilat and Sun (2017); Njoku and Susan (2016); Njimanted et al. (2016) [38, 40, 42].

\subsection{Cointegration Result}

The cointegration estimate is conducted on the variables with the view to determining the existence of long-run relationship between monetary policy indicators and the economic growth. The decision criteria for the presence of cointegrating vectors in the Johansen cointegration test is that the value of trace statistic and the maximum eigenvalue must be greater than its corresponding $5 \%$ critical values. Result for this test is presented as follows:

Table 4. Results of the unrestricted cointegration test

\begin{tabular}{lllll}
\hline \multicolumn{4}{l}{ Unrestricted cointegration test (Trace)** } \\
\hline $\begin{array}{l}\text { Null } \\
\text { hypothesis }\end{array}$ & Eigenvalue & $\begin{array}{l}\text { Trace } \\
\text { statistic }\end{array}$ & $\begin{array}{l}\mathbf{5 \%} \text { critical } \\
\text { value }\end{array}$ & P-value \\
\hline None* & 0.979125 & 220.8321 & 63.87610 & 0.0000 \\
At most $1 *$ & 0.757677 & 97.01755 & 42.91525 & 0.0000 \\
At most 2* & 0.615730 & 51.65810 & 25.87211 & 0.0000 \\
At most $3 *$ & 0.482066 & 21.05301 & 12.51798 & 0.0015 \\
\hline
\end{tabular}

\begin{tabular}{lllll}
\hline \multicolumn{4}{l}{ Unrestricted cointegration test (Maximum Eigenvalue)** } \\
\hline $\begin{array}{l}\text { Null } \\
\text { hypothesis }\end{array}$ & Eigenvalue & $\begin{array}{l}\text { Max-Eigen } \\
\text { statistic }\end{array}$ & $\begin{array}{l}\mathbf{5 \%} \text { critical } \\
\text { value }\end{array}$ & P-value \\
\hline None* & 0.979125 & 123.8145 & 32.11832 & 0.0000 \\
At most $1 *$ & 0.757677 & 45.35945 & 25.82321 & 0.0000 \\
At most $2 *$ & 0.615730 & 30.60509 & 19.38704 & 0.0008 \\
At most $3 *$ & 0.482066 & 21.05301 & 12.51798 & 0.0015 \\
\hline
\end{tabular}

Note: * denotes the rejection of hypothesis at $5 \%$ level

**Trace statistic indicates 4 cointegrating equation

**Maximum Eigenvalue indicates 4 cointegrating equation

Unrestricted cointegration test (Trace)**

Unrestricted cointegration test (Maximum Eigenvalue)**

Table 4 shows the results of unrestricted cointegrating relations based on the trace statistic and the maximum eigenvalue. It can be observed from the aforementioned Table 4 that both the trace statistic and the maximum eigenvalue indicate four (4) cointegrating equations at $5 \%$ significance level. Based on this, the study therefore reject the null hypothesis of no cointegrating relations and statistically accept the alternate hypothesis which indicates the existence of cointegrating vectors among the examined variables in the model. This implies the presence of long-run relationship between monetary policy (money supply, exchange rate, interest rate) and economic growth in Nigeria. In other words, the variables move together over a long period of time in a stationary means. This result is consistent with the literature as supported by Ayodeji and Oluwole (2018); Duskobilov (2017); Ahmad et al. (2016) [3, 4, 24].

\subsection{Diagnostic Test}

To ensure the validity of the findings, various diagnostic tests are conducted with the view to drawing reliable inferences. Among the diagnostic test includes the BreuschGodfrey serial correlation and heteroskedasticity test, respectively. For the serial correlation, the residuals generated by the model are not serially correlated with the Fstatistic value of 19.74 and a significant p-value of 0.0000 at all levels of significance. Hence, there is no serial correlation in model. For the Breusch-Pagan-Godfrey heteroskedasticity test, result indicates that all residuals are homoskedastic given the F-statistic value of 2.59 with significant $p$-value of 0.0687 at $10 \%$ level. This implies the existence of no heteroskedasticity in the model residuals thus, results are valid for inference.

\section{Conclusion and Policy Implications}

In an open economies, monetary policy is a strategic element of macroeconomic management which encourage stability and stimulate sustainable growth and development through its impact on macroeconomic indicators. In other words, monetary policy is believe to influence the employment level, price stability, growth of aggregate output and equilibrium in the balance of payment- for the case of developing economies. As hitherto, the impact of monetary policy on the economic growth and stability depends on how it is conducted through various channels and the independency of the apex bank to select the appropriate instruments for formulating the monetary policy of macroeconomic objectives. It is on this background that this study examine the effect and the relationship between monetary policy and economic growth in Nigeria by adopting the OLS technique and the cointegration test. Result indicates the existence of long-run relationship among the variables. Further results show that money supply has positive effect, while both exchange rate and interest rate have negative effect on the real GDP. By ways of recommendation, monetary authorities in Nigeria should adequately managed and monitored the growth level of money supply in order to avoid future inflation and realised the desired growth level. 
Given the socio-economic and political conditions in Nigeria, there is growing needs to formulate appropriate monetary measures which might encourage borrowing through sound and productive interest rate (particularly the lending rate) as well as stable exchange rate. This measure is expected to enhance domestic investment and increase the flow of foreign direct investment into the economy thereby expanding the market size and aggregate output towards financial and economic stability.

\section{References}

[1] Nwoko, N. M., \& Ihemeje, J. C. (2016). The impact of monetary policy on the economic growth of Nigeria. African Research Review, AFRREV, 10 (3), S/NO 42, 192-206.

[2] Anowor, O. F., \& Okorie, G. C. (2016). A reassessment of the impact of monetary policy on economic growth: Study of Nigeria. International Journal of Developing and Emerging Economies, 4 (1), 82-90.

[3] Duskobilov, U. (2017). Impact of economic regulation through monetary policy: Impact analysis of monetary policy tools on economic stability in Uzbekistan. International Journal of Innovation and Economic Development, 3 (5), 6569.

[4] Ahmad, D., Afzal, M., \& Ghani, U. (2016). Impact of Monetary Policy on Economic Growth Empirical Evidence of Pakistan. International Journal of Applied Economic Studies, 4 (6), 01-09.

[5] Onyeiwu, C. (2012). Monetary policy and economic growth of Nigeria. Journal of Economics and Sustainable Development, 3 (7), 62-70.

[6] Lennard, J. (2018). Did monetary policy matter? Narrative evidence from the classical gold standard. Explorations in Economic History, 68, 16-36.

[7] Chang, W., Chen, Y., \& Chang, J. (2013). Growth and welfare effects of monetary policy with endogenous fertility. Journal of Macroeconomics, 35, 117-130.

[8] Afrin, S. (2017). Monetary policy transmission in Bangladesh: Exploring the lending channel. Journal of Asian Economics, $49,60-80$.

[9] D'Aguanno, L. (2018). Monetary policy and wealth effects with international income transfer. Journal of Macroeconomics, 57, 210-230.

[10] Bhattacharya, J., Haslag, J., \& Martin, A. (2009). Optimal monetary policy and economic growth. European Economic Review, 53, 210-221.

[11] Smith, R. T. (1998). The Friedman rule and optimal monetary policy. Canadian Journal of Economics, 31 (2), 295-302.

[12] Twinoburyo, E. N., \& Odhiambo, N. M. (2018). Monetary policy and economic growth: A review of international literature. Journal of Central Banking Theory and Practice, 2, 123-137.

[13] Reed, R. R., \& Ghossoub, E. A. (2012). The effects of monetary policy at different stage of economic development. Economics letters, 117, 138-141.
[14] Aastveit, K. A., Natvik, G. J., \& Sola, S. (2017). Economic uncertainty and the influence of monetary policy. Journal of International Monetary and Finance, 76, 50-67.

[15] Kaminska, I., \& Roberts-Sklar, M. (2018). Volatility in equity markets and monetary policy rate uncertainty. Journal of Empirical Finance, 45, 68-83.

[16] Cantelmo, A., \& Melina, G. (2018). Monetary policy and the relative price of durable goods. Journal of Economic Dynamics and Control, 86, 01-48.

[17] Colletaz, G., Levieuge, G., \& Popescu, A. (2018). Monetary policy and long-run systematic risk taking. Journal of Economic Dynamics and Control, 86, 165-184.

[18] Najal, R. (2017). I S monetary policy necessary for the economic development of less developed countries with special reference to Pakistan. Business and Economic Journal, 8 (1), 01-03.

[19] Adigwe, P. K, Echekoba, F. N., \& Justus, B. C. O. (2015). Monetary policy and economic growth in Nigeria: A critical evaluation. IOSR Journal of Business and Management (IOSR-JBM), 17(2)/II, 110-119.

[20] Zhao, J., Chen, X., \& Hao, Y. (2018). Monetary policy, government control and capital investment: Evidence from china. China Journal of Accounting Research, 11, 233-254.

[21] Visokavičienè, B. (2014). Monetary policy in advanced economies during the global financial crisis: Lessons for Lithuania. EKONOMIKA, 93 (1), 40-56.

[22] Sulaiman, L. A., \& Migiro, S. O. (2014). The nexus between monetary policy and economic growth in Nigeria: a causality test. Public and Municipal Finance, 3 (2), 35-40.

[23] Ridhwan, M. M., de Groot, H. L. F., Nijkamp, P., \& Rietveld, P. (2010). The impact of monetary policy on economic activity - Evidence from a meta-analysis. Tinbergen Institute Discussion Paper, paper no. TI 2010-043/3.

[24] Ayodeji, A., \& Oluwole, A. (2018). Impact of monetary policy on economic growth in Nigeria. Open Access Library Journal, 5: e4320, 01-12.

[25] Dimitrijević, B., \& Lovre, I. (2013). Essay on monetary policy and economic growth. Journal of Central Banking Theory and Practice, 1, 111-138.

[26] Obeid, R., \& Awad, B. (2017). Effectiveness of monetary policy instruments on economic growth in Jordan using the vector error correction model. International Journal of Economics and Finance, 9 (11), 194-206.

[27] Chaudhry, I. S., Qamber, Y., Farooq, F. (2012). Monetary policy, inflation and economic growth in Pakistan: Exploring the co-integration and causality relationships. Pak. J. Commer. Soc. Sci., 6 (2), 332-347.

[28] Agbonlahor, O. (2014). The impact of monetary policy on the economy of the United Kingdom: A vector error correction model, European Scientific Journal, 10 (16), 19-42.

[29] Fasanya, I. O., Onakoya, A. B. O, Agboluaje, M. A. (2014). Does monetary policy influence economic growth in Nigeria? African Economic and Business Review, 12 (1), 01-32.

[30] Alavinasab, S. M. (2016). Monetary policy and economic growth: A case study of Iran. International Journal of Economics, Commerce and Management, IV (3), 234-244. 
[31] Komijani, A., Sargolzaei, M., Ahmad, R., \& Ahmadi, M. (2012). Asymmetric effects of monetary shocks on economic growth \& inflation: case study in Iran. International Journal of Business and Social Science, 3 (9), 224-230.

[32] Kamaan, C. K. (2014). The effect of monetary policy on economic growth in Kenya. International Journal of Business and Commerce, 3 (8), 11-24.

[33] Inam, U. S., Ime, B. S. (2017). Monetary policy and economic growth in Nigeria: evidence from Nigeria. Advances in Social Sciences Research Journal, 4(6), 41-59.

[34] Lut, M., \& Moolio, P. (2015). The impact of monetary policy on economic growth in Cambodia. Journal of Management for Global Sustainable Development, 1, 40-63.

[35] Younsi, M., \& Nafla, A. (2017). Financial stability, monetary policy, and economic growth: panel data evidence from developed and developing countries. J Knowl Econ. Springer nature. DOI 10.1007/s13132-017-0453-5.

[36] Precious, C., \& Palesa, M. (2014). Impact of monetary policy on economic growth: A case study of South Africa. Mediterranean Journal of Social Sciences, 5 (15), 76-84.

[37] Obadeyi, J. A., Okhiria, A., \& Afolabi, V. K. (2016). Evaluating the impact of monetary policy on the growth of emerging economy: Nigerian experience. American Journal of Economics, 6(5), 241-249.

[38] Srithilat, K., \& Sun, G. (2017). The impact of monetary policy on economic development: Evidence from Lao PDR. Global Journal of Human-Social Science, 17 (2), 9-15.

[39] Adediran, O. S., Mathew, O. A., Olopade, B. C., \& Adegboye, F. B. (2017). Monetary policy shocks and inclusive growth in Nigeria: A VAR approach. The International Journal of Humanities \& Social Studies, 5 (2), 173-179.

[40] Njoku, C. O., \& Susan, D. (2016). Monetary policy and economic stability in Nigeria: An empirical analysis. International Journal of Research in Management, Science \& Technology, 4(1), 70-80.

[41] Twinoburyo, E. N., \& Odhiambo, N. M. (2016). Monetary policy and economic growth in Kenya: The role of money supply and interest rates. UNISA Economic Research; Working Paper Series, working paper no 11/2016.
[42] Njimanted, F. G., Akume, D., Mukete, E. M. (2016). The impact of key monetary variables on the economic growth of the CEMAC zone. Expert Journal of Economics. 4 (2), 54-67.

[43] Ezeaku, H. C., Ibe, I. G., Ugwuanyi, U. B., Modebe, N. J., \& Agbaeze, E. K. (2018). Monetary policy transmission and industrial sector growth: Empirical evidence from Nigeria. SAGE Open, 1-12.

[44] Mallick, H. (2011). Monetary policy, construction sector output and housing prices in India: An emerging economy perspective. Applied Econometrics and International Development, 11 (1), 195-207.

[45] Furceri, D., Loungani, P., \& Zdzienicka, A. (2018). The effects of monetary policy shocks on inequality. Journal of International Money and Finance, 85, 168-186.

[46] Mumtaz, A., \& Theophilopoulou, A. (2017). The impact of monetary policy on inequality in the UK: An empirical analysis. European Economic Review, 98, 410-423.

[47] Voinea, L., Lovin, H., \& Cojocaru, A. (2018). The impact of inequality on the transmission of monetary policy. Journal of International Monetary Finance, 85, 236-250.

[48] Davtyan, K. (2017). The distributive effect of monetary policy: The top one percent makes the difference. Economic modelling, 65, 106-118.

[49] Ippolito, F., Ozdagli, A. K., \& Perez-Orive, A. (2018). The transmission of monetary policy through bank lending: The floating rate channel. Journal of Monetary Economics, 95, 4971.

[50] Balafas, N., Florackis, C., Kostakis, A. (2018). Monetary policy shocks and financially constrained stock returns: The effects of the financial crisis. International Review of Financial Analysis, 58, 69-90.

[51] Matousek, R., \& Solomon, H. (2018). Bank lending channel and monetary policy in Nigeria. Research in International Business and Finance, 45, 467-474.

[52] Ma, Y., \& Lin, X. (2016). Financial development and the effectiveness of monetary policy. Journal of Banking and Finance, 68, 01-11. 